\title{
Effect of variable water intake as mediated by dietary potassium carbonate supplementation on rumen dynamics in lactating dairy cows
}

\author{
S. E. Fraley, ${ }^{*}$ M. B. Hall, $†$ and T. D. Nennich ${ }^{* 1,2}$ \\ *Department of Animal Sciences, Purdue University, West Lafayette, IN 47906 \\ †US Dairy Forage Research Center, USDA-Agricultural Research Service, Madison, WI 53706
}

\begin{abstract}
Water is a critical nutrient for dairy cows, with intake varying with environment, production, and diet. However, little work has evaluated the effects of water intake on rumen parameters. Using dietary potassium carbonate $\left(\mathrm{K}_{2} \mathrm{CO}_{3}\right)$ as a $\mathrm{K}$ supplement to increase water intake, the objective of this study was to evaluate the effect of $\mathrm{K}_{2} \mathrm{CO}_{3}$ supplementation on water intake and on rumen parameters of lactating dairy cows. Nine ruminally cannulated, late-lactation Holstein cows $(207 \pm 12 \mathrm{~d}$ in milk) were randomly assigned to 1 of 3 treatments in a replicated $3 \times 3$ Latin square design with 18-d periods. Dietary treatments (on a dry matter basis) were no added $\mathrm{K}_{2} \mathrm{CO}_{3}$ (baseline dietary $\mathrm{K}$ levels of $1.67 \%$ dietary $\mathrm{K}$ ), $0.75 \%$ added dietary $\mathrm{K}$, and $1.5 \%$ added dietary $\mathrm{K}$. Cows were offered treatment diets for a 14-d adaption period followed by a 4-d collection period. Ruminal total, liquid, and dry matter digesta weights were determined by total rumen evacuations conducted $2 \mathrm{~h}$ after feeding on $\mathrm{d} 4$ of the collection period. Rumen fluid samples were collected to determine $\mathrm{pH}$, volatile fatty acids, and $\mathrm{NH}_{3}$ concentrations, and Co-EDTA was used to determine fractional liquid passage rate. Milk samples were collected twice daily during the collection period. Milk, milk fat, and protein yields showed quadratic responses with greatest yields for the $0.75 \%$ added dietary K treatment. Dry matter intake showed a quadratic response with $21.8 \mathrm{~kg} / \mathrm{d}$ for the $0.75 \%$ added dietary $\mathrm{K}$ treatment and 20.4 and $20.5 \mathrm{~kg} / \mathrm{d}$ for control and the $1.5 \%$ added dietary $\mathrm{K}$ treatment, respectively. Water intake increased linearly with increasing $\mathrm{K}_{2} \mathrm{CO}_{3}$ supplementation (102.4, 118.4, and $129.3 \mathrm{~L} / \mathrm{d}$ ) as did ruminal fractional liquid passage rate in the earlier hours after feeding $(0.118,0.135$, and 0.141 per hour). Total and wet weights of rumen contents declined linearly and dry weight tended to decline linearly as dietary $\mathrm{K}_{2} \mathrm{CO}_{3}$ increased, suggesting that
\end{abstract}

Received July 8, 2014.

Accepted January 14, 2015.

${ }^{1}$ Current address: Famo Feeds, Freeport, MN 56331.

${ }^{2}$ Corresponding author: tnennich@famofeeds.com the increasing water intake and fractional liquid passage rate with increasing $\mathrm{K}_{2} \mathrm{CO}_{3}$ increased the overall ruminal turnover rate. Ruminal ammonia concentrations declined linearly and $\mathrm{pH}$ increased linearly as $\mathrm{K}$ supplementation increased. As a molar percentage of total volatile fatty acids, acetate increased linearly as dietary $\mathrm{K}$ increased, though propionate declined. Increasing dietary $\mathrm{K}_{2} \mathrm{CO}_{3}$ and total $\mathrm{K}$ in the diets of lactating dairy cows increased water consumption and modified ruminal measures in ways suggesting that both liquid and total ruminal turnover were increased as both water and $\mathrm{K}$ intake increased.

Key words: dairy cow, potassium, water intake

\section{INTRODUCTION}

Water has long been established as the most essential nutrient for a lactating dairy cow, though it is often the one most overlooked. A typical lactating dairy cow will drink between 75 and $189 \mathrm{~L}$ of water daily, but that amount varies depending on several factors, including stage of lactation, environmental conditions, and diet intake and composition (Squires, 1988). Increased water intake has been associated with increased rumen turnover rates and decreased total ruminal VFA concentrations, with an altering of individual ruminal VFA concentrations (Rogers et al., 1979, 1982). West et al. (1987) concluded that increases in water consumption stimulate a greater turnover rate in the rumen. The changes in VFA concentrations were attributed to the fact that with an increase in rumen turnover rate, certain substrates are removed from the rumen before their fermentation occurs or is complete (West et al., 1987). However, little research has looked specifically at the effects of increased water intake on rumen digesta measures such as ruminal liquid passage rates or dry matter of rumen contents.

Few studies have evaluated the relationship between potassium $(\mathrm{K})$ and water intake. Potassium is often considered to be the principal intracellular cation within body tissues and is the third most abundant mineral element found within the body (NRC, 2001). It is well established that $\mathrm{K}$ plays a variety of roles within 
the body, including participation in the maintenance of osmotic potential within the cells and maintenance of normal kidney function (NRC, 2001; Harrison et al., 2011). Potassium is also a major component in the concept of DCAD and is part of the DCAD equation $[(\mathrm{Na}+\mathrm{K})-(\mathrm{S}+\mathrm{Cl})]$ (Tucker et al., 1991). Regarding the effect of $\mathrm{K}$ on water intake in dairy cattle, direct relationships between $\mathrm{K}$ intake and increased urinary excretion have been reported (Bannink et al., 1999; Nennich et al., 2006), from which one could infer that increased $\mathrm{K}$ intake results in greater water consumption. Recently, Appuhamy et al. (2014) reported that drinking water was positively related to dietary ash content independent of DMI, milk yield, and dietary DM content. However, intake of individual minerals was not evaluated in their study. Murphy (1992) developed an equation to predict water intake that included DMI, milk production, $\mathrm{Na}$ intake, and weekly minimum temperature, but $\mathrm{K}$ intake was not considered. Potassium carbonate $\left(\mathrm{K}_{2} \mathrm{CO}_{3}\right)$ has been evaluated as a dietary supplement of K. It has been shown to affect the lactation performance and DMI of dairy cattle (Schneider et al., 1984; West et al. 1987; Harrison et al., 2011), but its influence on water intake has not been reported.

Despite the overall importance of water to dairy cattle and the potential effects on rumen dynamics, little research has been done to evaluate the effect of water intake on rumen digesta measures. Although increasing dietary $\mathrm{K}$ supplementation would seem likely to increase water intake, it has not been well characterized in lactating dairy cows. The primary objective of this study was to evaluate the effect of changing water intake on ruminal digesta measures in lactating dairy cows. Supplemental dietary $\mathrm{K}$ as $\mathrm{K}_{2} \mathrm{CO}_{3}$ was used as the approach to increasing water intake, which also allowed evaluation of the effect of $\mathrm{K}_{2} \mathrm{CO}_{3}$ on water intake.

\section{MATERIALS AND METHODS}

\section{Design and Treatments}

Five multiparous (210 $\pm 10 \mathrm{DIM})$ and 4 primiparous $(205 \pm 6$ DIM) ruminally cannulated, Holstein cows were randomly assigned to a treatment sequence in a replicated $3 \times 3$ Latin square design with 18 -d periods. All experimental procedures were approved by the Purdue Animal Care and Use Committee (\#11-112). The 3 periods consisted of a 14-d adaptation period, followed by a 4-d period used for data and sample collection. Treatments included a control diet (LK), which included a baseline diet with $1.67 \%$ dietary K (DM basis); a diet (MK) with supplementation of $0.75 \%$ $\mathrm{K}(2.35 \%$ dietary $\mathrm{K}$ on a DM basis); and a diet (HK) with $1.5 \%$ supplemented dietary K $(3.08 \%$ dietary K on
Table 1. Ingredients of experimental $\operatorname{diets}^{1}$ for cows fed increasing levels of potassium carbonate

\begin{tabular}{lrrr}
\hline $\begin{array}{l}\text { Diet ingredient, } \\
\text { \% of DM }\end{array}$ & LK & MK & HK \\
\hline Corn silage & 38.2 & 38.2 & 38.2 \\
Alfalfa haylage & 14.9 & 14.9 & 14.9 \\
Orchardgrass hay & 2.8 & 2.8 & 2.8 \\
High-moisture corn & 16.4 & 16.4 & 16.4 \\
Soybean meal & 10.8 & 10.8 & 10.8 \\
DCAD Plus $^{2}$ & 0.0 & 1.6 & 3.2 \\
Soyhull pellet $_{\text {Megalac }}^{2}$ & 3.9 & 2.3 & 0.7 \\
Supplement $^{3}$ & 1.1 & 1.1 & 1.1 \\
Protein AA blend & 10.4 & 10.4 & 10.4 \\
& 5.4 & 5.4 & 5.4 \\
\hline
\end{tabular}

${ }^{1} \mathrm{LK}=$ baseline diet with $1.67 \%$ dietary $\mathrm{K} ; \mathrm{MK}=$ baseline diet with added $0.75 \%$ dietary $\mathrm{K} ; \mathrm{HK}=$ baseline diet with added $1.5 \%$ dietary $\mathrm{K}$.

${ }^{2}$ Arm and Hammer Animal Nutrition (Princeton, NJ).

${ }^{3}$ Supplement consisted of $38.3 \%$ fine-ground corn, $29 \%$ dried molasses, $7.3 \%$ Ca carbonate, $6.3 \%$ Na bicarbonate, $3.8 \%$ CaPhosMono, $3.8 \% \mathrm{NaCl}$ salt, 2.5\% Diamond V XP Yeast (Diamond V, Cedar Rapids, IA), $2.3 \%$ magnesium oxide, $1.8 \%$ urea, $1.8 \%$ Ca sulfate, $1.8 \%$ Omnigen AF (Prince Agri Products, Quincy, IL), 1.1\% GSC TMV, $0.3 \%$ niacin $(99 \%), 0.2 \%$ vitamin $\mathrm{E}(20,000)$, and $0.07 \%$ Rumensin 90 (Elanco Animal Health, Greenfield, IN).

a DM basis). Potassium carbonate (DCAD Plus, Arm and Hammer Animal Nutrition, Princeton, NJ) was used for $\mathrm{K}$ supplementation and was substituted for soyhulls (Table 1). All diets were formulated to meet or exceed NRC (2001) requirements by up to $10 \%$. All cows were fed their respective treatment diets throughout each 18-d period.

\section{Data and Sample Collection}

Cows were housed in individual tie stalls in the metabolism unit at the Purdue University Dairy Teaching and Research Center. Stalls consisted of rubber mattresses that were bedded with sawdust and cleaned twice daily. Cows had access to feed ad libitum; orts and feed offered were weighed and recorded for each cow daily and daily DMI calculated. Feed was offered to cows at approximately $0700 \mathrm{~h}$ daily using a Calan Data Ranger (American Calan Inc., Northwood, NH). Cows were fed at $110 \%$ of expected intake. Water meters $(3 / 4$-inch Multi-Jet Water Meter, Master Meter, Fort Worth, TX) were installed on each individual water cup in each tie-stall, and individual cow water intake was recorded each day during the collection period. Ort samples collected daily during the collection period were composited between cows on the same dietary treatments. Individual feed ingredients were collected on d 1 and 4 of the collection period and were composited within period. Drinking water samples were collected on the first day of every treatment period. Samples were frozen at $-20^{\circ} \mathrm{C}$ until water quality analysis was conducted. 
Cows were milked twice daily at 0530 and $1630 \mathrm{~h}$, and milk was sampled at each milking during the collection period. Milk samples were collected in sealable tubes containing a preservative and refrigerated for later determination of milk composition. Milk weights were collected at each milking to determine daily milk yield for individual cows. Body weights were measured on d 1 and 4 of collection periods after morning milking.

The fractional liquid passage rate (lkp) from the rumen was determined using Co-EDTA as a liquid phase marker [prepared as Co-EDTA (EDTA) according to Udén et al., 1980] on d 2 and 3 of the collection period. A solution was made that contained $25 \mathrm{~g}$ of dried CoEDTA crystal in $1 \mathrm{~L}$ of distilled $\mathrm{H}_{2} \mathrm{O}$ for dosing cows. Cows were dosed $2 \mathrm{~h}$ after feeding. A predosing rumen fluid sample was taken as a reference point before each cow was infused with $60 \mathrm{~mL}$ of Co-EDTA solution that was administered via rumen cannula using a syringe and tube to infuse the solution to the caudal, dorsal, and ventral areas of the rumen. The tube was then rinsed with $160 \mathrm{~mL}$ of distilled $\mathrm{H}_{2} \mathrm{O}$. Rumen fluid samples were collected at the following times: $0,3,6$, $9,12,18$, and $24 \mathrm{~h}$ after dosing as well as $2 \mathrm{~h}$ after feeding on $\mathrm{d} 4$ of the collection period $(150 \mathrm{~mL}$ of total volume at each collection). Rumen fluid samples were collected via rumen cannula by applying vacuum pressure to a hand-operated tube with a suction strainer from the caudal, dorsal, and ventral area of the rumen. The rumen fluid samples collected at each sampling time were used for immediate determination of rumen pH using a Hanna Combo pH meter (HI 98129; Hanna Instruments, Ann Arbor, MI) and further subsampled. A subsample of $20 \mathrm{~mL}$ was acidified with $25 \%$ (wt/vol) meta-phosphoric acid ( $4 \mathrm{~mL}$ of acid per $20 \mathrm{~mL}$ of fluid) and immediately frozen at $-20^{\circ} \mathrm{C}$ for later analysis of VFA and $\mathrm{NH}_{3}$ concentrations. The remaining samples were immediately frozen at $-20^{\circ} \mathrm{C}$ to be analyzed for Co for calculation of $1 \mathrm{kp}$.

On d 4 of the collection period, rumen contents were evacuated manually through the rumen cannula $2 \mathrm{~h}$ after feeding and were weighed to determine total rumen content mass. For accurate subsampling, every tenth handful of digesta (10\%) was placed in a separate container throughout evacuation (Voelker Linton and Allen, 2008). This subsample was then mixed thoroughly and further subsampled and dried in a $55^{\circ} \mathrm{C}$ forced-air oven for $48 \mathrm{~h}$ to determine total rumen digesta DM, liquid, and DM percentage, with remaining digesta subsamples frozen at $-20^{\circ} \mathrm{C}$.

Blood was sampled from the coccygeal vessel using Vacutainer tubes (Becton Dickinson Vacutainer Systems, Franklin Lakes, NJ) on d 4 of the collection period, $2 \mathrm{~h}$ after feeding. One sample was collected from each cow using a Vacutainer tube containing Na- heparin and immediately transported to the laboratory where the tubes were centrifuged at $4^{\circ} \mathrm{C}(3,000 \times g)$ for $15 \mathrm{~min}$. Plasma was harvested, and the samples were stored at $-20^{\circ} \mathrm{C}$ for later determination of plasma urea N (Stanbio Urea Nitrogen kit, Stanbio Laboratory, Boerne, TX; diacetylmonoxime methodology) based on procedures of Fearon (1939) and Wybenga et al. (1971). Fecal samples were collected $2 \mathrm{~h}$ after feeding on $\mathrm{d} 4$ of the collection period and were used for immediate determination of fecal $\mathrm{pH}$ using the method described by Gressley and Armentano (2005). The remaining sample was then dried in a forced-air oven at $55^{\circ} \mathrm{C}$ for $48 \mathrm{~h}$ to determine fecal DM percentage.

\section{Sample Analysis}

Individual feed ingredients, diet samples, and orts were dried in a $55^{\circ} \mathrm{C}$ forced-air oven for $48 \mathrm{~h}$ and analyzed to determine DM concentration. All samples were ground through a Wiley mill (1-mm screen; Arthur H. Thomas, Philadelphia, PA). All composited samples were sent to DairyOne Forage Analysis Laboratory (Ithaca, NY) for chemical analysis. The analyses reported during each period included CP (AOAC International, 2000; method 990.03), ADF (AOAC International, 2000, using an Ankom A200 Digestion Unit; Ankom, Macedon, NY), NDF (using heat-stable $\alpha$-amylase and sodium sulfite; Ankom, 2011; method 6, Macedon, NY; solutions as in Van Soest et al., 1991; using an Ankom A200 Digestion Unit), and minerals ( $\mathrm{Ca}, \mathrm{P}, \mathrm{Mg}, \mathrm{K}, \mathrm{Na}$, and $\mathrm{S}$; Thermo IRIS Advantage HX or Intrepid Inductively Coupled Plasma Radial Spectrometer after microwave digestion; Thermo Fisher Scientific Inc., Waltham, MA) (Table $2)$. The DCAD of the diet was determined using the equation $(\mathrm{Na}+\mathrm{K})-(\mathrm{S}+\mathrm{Cl})$. Milk was analyzed for fat, true protein, SCC, milk urea N, lactose, and total solids using mid-infrared spectroscopy according to AOAC International (2006) methods (DairyOne Cooperative, Ithaca, NY).

Drinking water samples were sent to DairyOne Water Analysis Laboratory (Ithaca, NY) for waterquality analysis. The analyses reported for each period consisted of $\mathrm{pH}$ (Thermo Orion Posi-pHlo SympHony Electrode and Thermo Orion 410 A meter), nitrates (RQflex reflectometer method), sulfates (turbidimetric method, 957-13-3; based upon principles in AOAC International, 2006; method 973.57), total dissolved solids (conductivity method; ES\&D model 76 conductivity meter), hardness as $\mathrm{CaCO}_{3}$ equivalent [calculated as $(\mathrm{Ca} \times 2.5)+(\mathrm{Mg} \times 4.1)]$, and minerals $(\mathrm{Ca}, \mathrm{P}$, $\mathrm{Mg}, \mathrm{K}, \mathrm{Na}, \mathrm{Fe}, \mathrm{Zn}, \mathrm{Cu}, \mathrm{Mn}$, and $\mathrm{Mo}$; analyzed by direct aspiration with no sample preparation by Thermo IRIS Advantage Hx or ICAP 6300 Inductively Coupled Plasma Radial Spectrometer, Madison, WI). 
Table 2. Chemical composition of experimental $\operatorname{diets}^{1}$

\begin{tabular}{lccc}
\hline $\begin{array}{l}\text { Composition, \% of DM } \\
\text { unless otherwise noted }\end{array}$ & LK & MK & HK \\
\hline $\mathrm{DM}, \%$ & 50.8 & 49.3 & 48.6 \\
$\mathrm{CP}$ & 17.7 & 17.5 & 17.3 \\
$\mathrm{ADF}$ & 19.9 & 19.2 & 18.4 \\
$\mathrm{NDF}$ & 31.8 & 30.7 & 29.6 \\
$\mathrm{TDN}$ & 74.0 & 73.0 & 72.1 \\
$\mathrm{NE}, \mathrm{Mcal} / \mathrm{kg}$ & 1.72 & 1.69 & 1.67 \\
$\mathrm{Ca}$ & 1.05 & 1.05 & 1.04 \\
$\mathrm{P}$ & 0.41 & 0.41 & 0.41 \\
$\mathrm{Mg}$ & 0.38 & 0.37 & 0.37 \\
$\mathrm{~K}$ & 1.67 & 2.35 & 3.08 \\
$\mathrm{Na}$ & 0.15 & 0.17 & 0.18 \\
$\mathrm{~S}$ & 0.27 & 0.26 & 0.26 \\
$\mathrm{Cl}$ & 0.60 & 0.60 & 0.59 \\
$\mathrm{Fe}, \mathrm{mg} / \mathrm{kg}$ & 262.1 & 255.9 & 250.1 \\
$\mathrm{Zn}, \mathrm{mg} / \mathrm{kg}$ & 111.2 & 110.5 & 109.9 \\
$\mathrm{Cu}, \mathrm{mg} / \mathrm{kg}$ & 26.6 & 26.5 & 26.4 \\
$\mathrm{Mn}, \mathrm{mg} / \mathrm{kg}$ & 113.5 & 113.3 & 113.1 \\
$\mathrm{DCAD}{ }^{2} \mathrm{mEq} / 100 \mathrm{~g}$ & 16.0 & 34.1 & 53.5 \\
\hline
\end{tabular}

${ }^{1} \mathrm{LK}=$ baseline diet with $1.67 \%$ dietary $\mathrm{K} ; \mathrm{MK}=$ baseline diet with added $0.75 \%$ dietary $\mathrm{K} ; \mathrm{HK}=$ baseline diet with added $1.5 \%$ dietary K.

${ }^{2} \mathrm{DCAD}$ was determined using the equation $(\mathrm{Na}+\mathrm{K})-(\mathrm{S}+\mathrm{Cl})$.

Rumen fluid samples containing Co-EDTA were sent to Analab (a division of Agri-King, Fulton, IL) for Co concentration determination (AOAC International, 2006; method 985.01). Rumen ammonia was analyzed using the Kjeldahl N method (Kjeltec 2300 Autoanalyzer, Foss Tecator AB, Hoganas, Sweden) without undergoing acid digestion. Analysis for VFA was conducted by gas chromatography/flame ionization detector analysis (model 7890A Agilent Technologies, Santa Clara, CA) using a Nukol capillary column (30 $\mathrm{m}$ in length, $0.25 \mathrm{~mm}$ i.d., $25 \mu$ phase, Supelco Inc., Bellefonte, PA). Oven temperature program was 90 to $150^{\circ} \mathrm{C}$ at $10^{\circ} \mathrm{C} / \mathrm{min}$, using helium carrier gas maintained at 551,580.6 Pa. The injector port was set at $270^{\circ} \mathrm{C}$, and split injections were made at a $30: 1$ split ratio. The flame-ionization detector conditions were as follows: temperature of $300^{\circ} \mathrm{C}$, air at $400 \mathrm{~mL} / \mathrm{min}$, and $\mathrm{H}^{2}$ at $40 \mathrm{~mL} / \mathrm{min}$ with makeup helium flow of $26 \mathrm{~mL} /$ min. The VFA standard contained $100 \mu \mathrm{L}$ of WSFA-2 (Sigma-Aldrich, St. Louis, MO) and $25 \mu \mathrm{L}$ of MIS solution. The MIS solution contained 25\% (wt/vol) metaphosphoric acid with 2-ethylbutyric acid (109959-1L, Sigma Aldrich) added to give a final concentration of 3 to $4 \mathrm{~m} M$ in the standard and samples.

Mineral analyses were performed on the supernatant of unacidified rumen fluid samples centrifuged at 11,800 $\times g$ for $45 \mathrm{~min}$ at $5^{\circ} \mathrm{C}$. Minerals were analyzed using an inductively coupled plasma optical emission spectrometer (Optima 5300-DV, Perkin-Elmer, Waltham, MA; AOAC International, 2006; method 953.01).
The $1 \mathrm{kp}$ from the rumen was determined as the slope of the natural log of Co concentration over time. This calculation was performed on all time points ( 0 through $24 \mathrm{~h}$ ) and for early ( 0 through $9 \mathrm{~h}$ ) and late (9 through $24 \mathrm{~h}$ ) time frames. The basis for estimating the rates in earlier and later time frames is the work of Gasa et al. (1991), who described a 2-phase linear model to more accurately describe disappearance of Co used as a marker for the ruminal liquid fraction. Two data points in period 3 were removed because the regression lines were associated with very low $R^{2}$ values $\left(R^{2}=0.15\right.$ to 0.43 ) in the presence of them compared with regression lines with $\mathrm{R}^{2}>0.85$ in their absence.

\section{Statistical Analysis}

Data from the collection period for all production measurements were used for statistical analysis. Data were analyzed using the MIXED procedure of SAS using both linear and quadratic contrasts (version 9.2, SAS Institute Inc., Cary, NC) according to the following model:

$$
Y_{i k j l}=\mu+T_{i}+P_{j}+S_{l}+C_{k}+T P_{i j}+T S_{i l}+e_{i j k l,}
$$

where $Y_{i k j l}$ is the dependent variable, $\mu$ is the overall mean, $T_{i}$ is the fixed effect of dietary treatment $(i=1$ to 3$), P_{j}$ is the fixed effect of the experimental period $(j$ $=1$ to 3$), S_{l}$ is the fixed effect of Latin square replicate ( $l=1$ to 3 ), $C_{k}$ is the random effect of cow within Latin Square $(k=1$ to 9$), T P_{i j}$ is the interaction of period and treatment, $T S_{i l}$ is the interaction between treatment and Latin square replicate, and $e_{i j k l}$ is the residual error that is assumed to be independent, identical, and normally distributed with a mean of 0 . The early- and late-time-frame $\mathrm{kp}$ data were analyzed using the same model but with treatment analyzed as added dietary $\mathrm{K}(0,0.75$, and $1.50 \%)$ evaluated as a continuous variable. In these analyses, factors other than treatment, period, and square were removed from the model if $P>$ 0.25 . Treatment effects and interactions were declared significant at $P \leq 0.05$ and tendencies for treatment effects at $0.10 \geq P>0.05$.

Backward stepwise regression analyses were performed to assess which variables considerably $(P \leq$ 0.10 ) affected free water intake and lkp at 0 to $9 \mathrm{~h}$. Dry matter intake, milk yield, and feed $\mathrm{K}$ intake were first regressed against $\mathrm{lkp}$ and free water intake. These variables were then regressed with VFA moles, rumen liquid amount, and rumen DM amount. Additionally, minerals besides $\mathrm{K}$ that were found in water were not used because they were correlated with water intake, and the intake of the minerals increased with increasing 
water intake (data not shown). Ruminal VFA concentrations were not used as predictor variables because variation in rumen liquid volumes causes them not to be on the equivalent basis required for statistical comparisons (Hall et al., 2014).

\section{RESULTS AND DISCUSSION}

\section{DMI and Water Intake}

Chemical analyses of diets are found in Table 2. As K was increased in the diet, the dietary $\mathrm{CP}$ concentration numerically decreased from 17.7 to $17.3 \%$ of diet DM. The numerical differences in $\mathrm{CP}$ and other nutrients were due to the substitution of $\mathrm{K}_{2} \mathrm{CO}_{3}$ for soyhulls in the treatment diets. Potassium increased as expected when comparing the LK diet with both of the $\mathrm{K}$ diets (1.67, 2.35, and $3.08 \%$ on a DM basis; respectively). Similarly, DCAD levels increased as K levels increased in the diets (Table 2).

When comparing DMI among treatments (Table 3 ), a quadratic effect $(P<0.01)$ was observed with the MK cows eating an average of $1.4 \mathrm{~kg} / \mathrm{d}$ more than cows offered either the LK or HK diets. Similar to the results seen in this study where feeding a high-DCAD diet, which was achieved by supplementing $\mathrm{K}_{2} \mathrm{CO}_{3}$, decreased DMI, Roche et al. (2003) also demonstrated that feeding diets with high levels of DCAD (above 52 $\mathrm{mEq} / 100 \mathrm{~g}$ ) was detrimental to feed intake. Results of other studies have shown that cows fed diets containing higher levels of $\mathrm{K}_{2} \mathrm{CO}_{3}$ (1.53\% dietary $\mathrm{K}$, DM basis) had greater DMI as compared with cows on a control diet (West et al., 1987). Sanchez et al. (1994) found that
DCAD ranging from 17 to 38 and 25 to $40 \mathrm{mEq} / 100 \mathrm{~g}$ of DM improved DMI. However, not all studies agree with these findings. Schneider et al. (1984) found that potassium-bicarbonate supplementation of $1.0 \%$ of diet DM had detrimental effects on DMI, and they attributed the decrease in intake to poor palatability. Poor palatability and the effect of a high DCAD level may be the causes for the reduced DMI of the cows on the HK diet in the present study. In a study done by Delaquis and Block (1995), increasing levels of DCAD did increase DMI; however, these results were limited to cows in early- and mid-lactation, with no effect of increasing DCAD on DMI observed for those cows in late lactation, which is the stage of lactation of the cows in the present study.

Intake of drinking water linearly increased as $\mathrm{K}$ increased in the diet $(P=0.001$; Table 5$)$. The relationship between increased drinking-water intake and increased $\mathrm{Na}$ intake has been well established, and Murphy (1992) developed an equation to predict water intake that included $\mathrm{Na}$ intake as a factor. Previous research has also found that increased dietary $\mathrm{K}$ causes an increase in water consumption. Omer and Roberts (1967) evaluated the levels of dietary K on water intake in beef heifers and found that high levels of dietary $\mathrm{K}$ (4.24\% DM basis) resulted in increased water consumption compared with a diet containing $1.71 \% \mathrm{~K}$. This group concluded that the increase in water consumption, and the resulting increase in urine volume, occurred because the excessive $\mathrm{K}$ ions may have had a diuretic effect, which caused the increase in water consumption to maintain proper body water balance (Omer and Roberts, 1967). Corresponding with the

Table 3. The effect of increasing levels of dietary potassium on DMI, milk yield, and milk composition

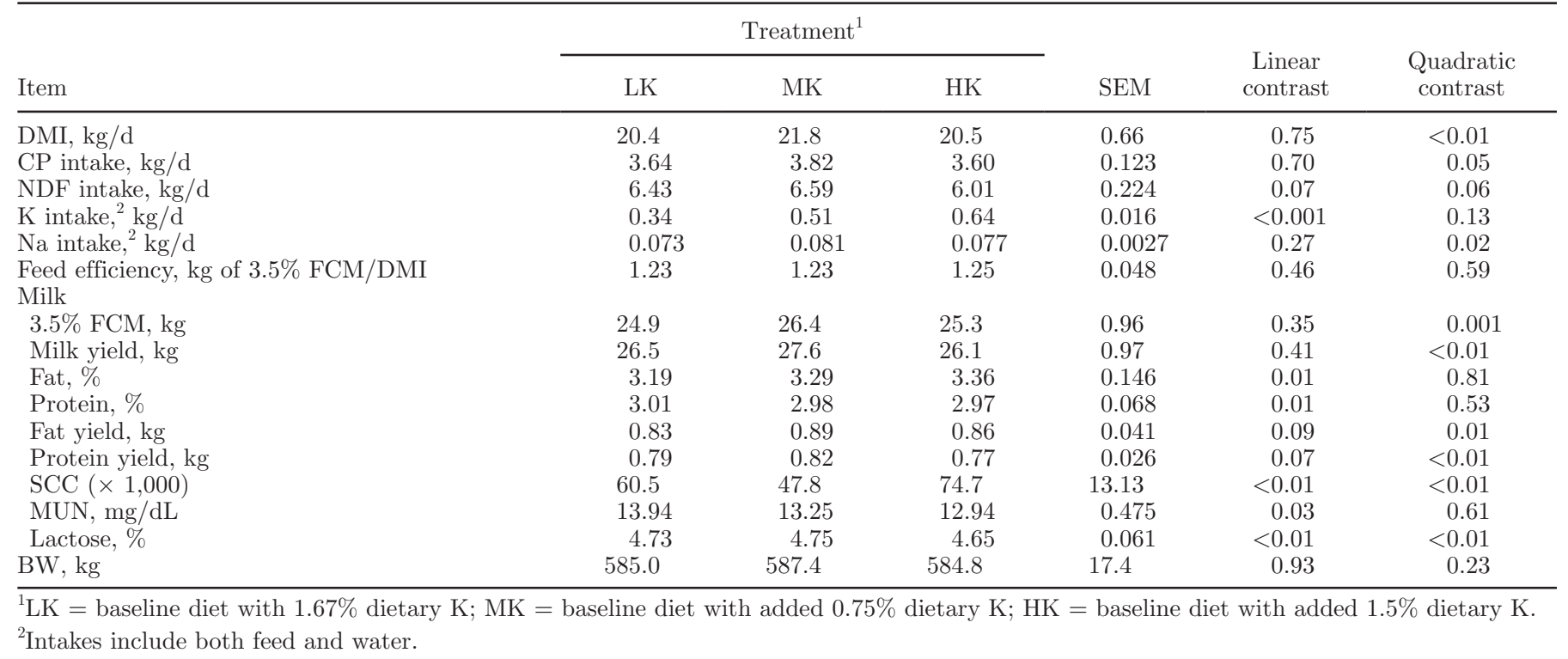


DMI results, water intake from feed showed a quadratic response $(P=0.008)$, with the cows on the MK diet consuming the most water from feed when compared with cows consuming either LK or HK. Combining both free water intake and intake of water through feed resulted in a linear effect $(P=0.001)$ of dietary $\mathrm{K}$ levels on total water consumption.

From the regression analyses, free water intake in the present study was best described by the equation (SE; $P$-value in parentheses) $-19.869(38.192 ; 0.61)+$ $83.66(23.79 ;<0.01) \times$ Feed $\mathrm{K}$ intake, $\mathrm{kg} / \mathrm{d}+0.1623$ $(0.0673 ; 0.02) \times \mathrm{BW}, \mathrm{kg}$ [adjusted $\mathrm{R}^{2}=0.46$, root mean square error $(\mathbf{R M S E})=16.27, \mathrm{CV}=13.9 \%]$ whether external, or ruminal and external measures were used. This differs from the results of Murphy (1992) in which DMI, milk production, and Na intake were the better predictors of water intake. The present study was not designed to attempt a global prediction of water intake, and the number of observations and their variability were likely insufficient to capture those effects. Additionally, Na intake could not be considered in the present study because a main factor for its increased intake was increased consumption of water containing Na. The relationship between feed $\mathrm{K}$ intake alone explained $36 \%$ $\left(\mathrm{R}^{2}=0.36\right)$ of the variability in water intake.

The results of this study indicate that total water intake can be affected by nutrient composition of the diet. The differing water intakes have potential effects both with interpretation of concentrations of various parameters collected from the rumen, as well as from the aspect of water usage on the farm itself. With the increase in water consumption, producers need to be aware of the potential to increase total farm water usage. Although in some areas that is not a concern, instances do exist when increasing water usage on farms would not be beneficial to the producer. These include areas where water usage is restricted as well as times of drought.

Overall, the water at the Purdue University Dairy Teaching and Research Center was of good quality (Table 4). Primary areas of concern in regards to water quality and dairy cattle include total dissolved solids, sulfur, sulfate and chloride, nitrates, iron, and fluoride (Beede, 2005). All of the parameters tested presented values well below critical problem points identified for dairy cattle, indicating that water quality during this study should not have negatively affected water intake.

\section{Milk Yield and Milk Components}

In line with the DMI results, dietary $\mathrm{K}$ level had a quadratic effect $(P<0.001)$ on milk yield (Table 3 ). Cows fed the MK diet produced, on average, $1.3 \mathrm{~kg} / \mathrm{d}$ more than either the LK or HK diets. There was a similar quadratic effect on both milk fat and protein yields $(P=0.01$ and $P<0.01$, respectively), with the cows on the MK diets producing more kilograms per day of both protein and milk fat than cows on either of the other diets. Harrison et al. (2011) described the role of $\mathrm{K}$ in milk production as being linked to DCAD, specifically because $\mathrm{K}$ is one of the cations that increases the DCAD level. Similar to what was observed in the present study, research has shown that increasing DCAD can result in a quadratic response in milk yield (West et al., 1991; Sanchez et al., 1994; Hu and Murphy, 2004). Hu and Murphy (2004) showed that increasing DCAD resulted in a quadratic response in milk yield, with the optimum range in DCAD concentration occurring between 25 to $40 \mathrm{mEq} / 100 \mathrm{~g}$, a range that encompasses the MK diet in the present study. Similar to the observed milk-yield response, 3.5\% FCM showed a quadratic effect, with cows on the MK diet having the greatest $3.5 \%$ FCM when compared with either the LK cows or the HK cows $(P=0.001)$. Despite this quadratic response and the similar response in DMI, feed efficiency did not differ detectably between treatments.

Despite the quadratic effect on milk yield, milk fat concentration increased linearly $(P=0.01)$ as $\mathrm{K}$ increased in the diets. Also, milk protein percentage decreased linearly $(P=0.01)$ as $\mathrm{K}$ increased in the diets. The changes in concentrations of milk composition seen in this study are similar to previous research that found that cows fed a higher level of $\mathrm{K}_{2} \mathrm{CO}_{3}(1.85 \% \mathrm{DM})$ had greater milk fat percentages than cows on control diets (West et al., 1987). Harrison et al. (2012) also reported an increase in milk yield and milk fat concentrations as dietary $\mathrm{K}$ increased from $1.28 \%$ (DM basis) to $2.07 \%$ (DM basis); however, DMI did not differ between treat-

Table 4. Average water analysis results

\begin{tabular}{lc}
\hline Item & Study average (SD) \\
\hline Nitrates, $\mathrm{mg} / \mathrm{kg}$ & $\mathrm{ND}^{1}$ \\
Nitrates-N, mg/kg & $\mathrm{ND}$ \\
Sulfates, $\mathrm{mg} / \mathrm{kg}$ & $49.7(2.08)$ \\
Sulfates - sulfur, mg/kg & $16.3(0.58)$ \\
Chlorides, $\mathrm{mg} / \mathrm{kg}$ & $9.0(1.00)$ \\
Hardness, $\mathrm{mg}$ of $\mathrm{CaCO} / \mathrm{kg}$ & $218.0(14.18)$ \\
Total dissolved solids, mg/kg & $260.3(17.79)$ \\
$\mathrm{Ca}, \mathrm{mg} / \mathrm{kg}$ & $38.3(4.90)$ \\
$\mathrm{P}, \mathrm{mg} / \mathrm{kg}$ & $<0.1$ \\
$\mathrm{Mg}, \mathrm{mg} / \mathrm{kg}$ & $30.0(0.68)$ \\
$\mathrm{K}, \mathrm{mg} / \mathrm{kg}$ & $2.4(0.12)$ \\
$\mathrm{Na}, \mathrm{mg} / \mathrm{kg}$ & $7.0(0.15)$ \\
$\mathrm{Fe}, \mathrm{mg} / \mathrm{kg}$ & $0.15(0.014)$ \\
$\mathrm{Zn}, \mathrm{mg} / \mathrm{kg}$ & $<0.01$ \\
$\mathrm{Cu}, \mathrm{mg} / \mathrm{kg}$ & 0.01 \\
$\mathrm{Mn}, \mathrm{mg} / \mathrm{kg}$ & 0.01 \\
$\mathrm{Mo}, \mathrm{mg} / \mathrm{kg}$ & 0.01 \\
$\mathrm{pH}$ & $7.3(0.10)$ \\
\hline
\end{tabular}

${ }^{1} \mathrm{ND}=$ none detected. 
ment groups. A study in Texas found that milk fat increased in cows fed diets containing greater levels of $\mathrm{K}_{2} \mathrm{CO}_{3}$ (West et al., 1986), which was attributed to greater acetate:propionate ratios in the rumen. Similar to the finding in this study, West et al. (1986) observed a decrease in milk protein concentrations in cows fed diets containing $\mathrm{K}_{2} \mathrm{CO}_{3}$ compared with those fed sodium carbonate; however, these researchers attributed the depression in milk protein concentrations to a dilution effect because cows fed the $\mathrm{K}_{2} \mathrm{CO}_{3}$ diet had greater production than the sodium carbonate treatment. Alternatively, another possible basis for increasing fat test is that the increased ruminal $\mathrm{lkp}$ noted with increasing $\mathrm{K}_{2} \mathrm{CO}_{3}$ supplementation (see below) may reduce residence time of long-chain fatty acids in the rumen. Shorter retention time in the rumen could reduce the extent of biohydrogenation by rumen microbes that the fats undergo, and so produce and deliver to the cow less of the unsaturated fatty acids that can have negative effects on fat test (T. Jenkins, Clemson University, Clemson, SC, personal communication).

\section{Rumen and Fecal Parameters}

Weights of both total rumen digesta and digesta liquid showed a linear decrease $(P=0.01$ and $P=0.01$, respectively) and digesta DM weight tended to decline linearly $(P=0.09)$ with increasing dietary $\mathrm{K}$ (Table 5$)$, despite or perhaps because of the concurrent increase in water intake. Although water intake increased as K level increased, DM concentration of rumen contents did not differ among treatments. West et al. (1987) concluded that a diet high in soluble particles, such as minerals, increases osmotic potential in the rumen, which helps to stimulate water consumption and helps to contribute to a greater turnover in the rumen. A greater turnover rate in the rumen could contribute to the decreases in rumen contents despite the increase in water consumption. Although no differences were detected in the $1 \mathrm{kp}$ when determined between 0 to 24 $\mathrm{h}$ and 9 to $24 \mathrm{~h}(P>0.54$ for both $), \mathrm{lkp}$ had a linear increase with increasing dietary $\mathrm{K}$ from 0 through $9 \mathrm{~h}$ $(P=0.04$; Table 5$)$. The more rapid $\mathrm{lkp}$ in earlier hours after feeding as compared with later hours is in agreement with observations reported by Gasa et al. (1991), who noted a break point in the ruminal Co concentration curve at approximately $10 \mathrm{~h}$ after introduction of Co-EDTA to the rumen and $8 \mathrm{~h}$ after their initial feeding of the day. The increasing $\mathrm{lkp}$ are consistent with the increased water intakes of cows as K supplementation increased. The linear decreases in ruminal liquid and total digesta weights and the tendency for a linear decrease in ruminal DM weight suggests that the increased lkp may have increased washout of solids and liquid from the rumen. Although the increase in lkp in the rumen most likely accounts for the majority of changes in rumen liquid amounts in relation to the differences in drinking-water intake, there was also the potential for movement of water across the reticulorumen wall (Appuhamy et al., 2014) to have played a factor in the liquid amounts measured in the rumen.

When ruminal measures were not used as independent variables, only free water intake significantly determined the 0 -to-9-h lkp from the rumen (SE; $P$-value in parentheses): $0.02565(0.03040 ; 0.41)+0.000907$ $(0.000254 ;<0.01) \times$ free water intake, $\mathrm{kg} / \mathrm{d}$ (adjusted $\left.\mathrm{R}^{2}=0.35, \mathrm{RMSE}=0.0275, \mathrm{CV}=20.8 \%\right)$. When ruminal measures were used, rumen VFA moles had a negative effect on the lkp independent of the positive effect of free water intake (SE; $P$-value in parentheses): $0.07447(0.03787 ; 0.06)+0.000791(0.000247 ;<0.01)$ $\times$ free water intake, $\mathrm{kg} / \mathrm{d}-0.00425(0.00215 ; 0.06)$ $\times$ VFA moles (adjusted $\mathrm{R}^{2}=0.39, \mathrm{RMSE}=0.0260$, $\mathrm{CV}=19.6 \%)$. The moles of VFA measured $2 \mathrm{~h}$ after feeding is highly correlated with the amount of liquid in the rumen, but it is uncertain as to why this would be negatively correlated with $\mathrm{kp}$. With liquid passage measured as a dilution of Co-EDTA, passage from the rumen or dilution within the rumen would both be detected as "passage." Feed K intake alone was significantly associated with the lkp during 0 to $9 \mathrm{~h}$ (SE; $P$-value in parentheses): $0.07876(0.02280 ;<0.01)+$ $0.10738(0.04387 ; 0.02) \times$ feed $\mathrm{K}$ intake, $\mathrm{kg} / \mathrm{d}$ (adjusted $\mathrm{R}^{2}=0.17, \mathrm{RMSE}=0.030, \mathrm{CV}=23.0 \%$ ). The correlation coefficients of variables used in the regressions for 0-to-9-h lkp and free water intake are shown in Table 6.

Total concentrations of VFA did not differ among treatments $(P>0.43)$; however, acetate $(\mu \mathrm{mol} / \mathrm{mL})$ tended to increase as dietary $\mathrm{K}$ increased $(P=0.06)$. Propionate $(\mu \mathrm{mol} / \mathrm{mL})$ had a linear decrease, and butyrate $(\mu \mathrm{mol} / \mathrm{mL})$ tended to decrease as well $(P=0.04$ and $P=0.09$, respectively; Table 5$)$. However, at $2 \mathrm{~h}$ after feeding, the moles of total VFA, propionate, and butyrate present in the rumen showed linear declines $(P<0.02)$ and moles of acetate tended to show a linear decline $(P=0.08)$ as dietary $\mathrm{K}$ increased. In this case, moles of VFA allow a more reliable comparison of treatment effects; because the amounts of liquid in the rumen differed by dietary treatment, the concentrations are not on the equivalent-volume basis needed to allow appropriate comparison. In the case of acetate, additional $\mathrm{K}$ supplementation increased acetate concentrations, but overall amounts of acetate actually declined in the rumen. Evaluation of VFA pool sizes in the rumen gave a very different interpretation than that obtained from evaluating concentrations. Focusing on only concentrations of VFA in the rumen, without accounting for liquid flow and dilution, could result in 
FRALEY ET AL.

Table 5. The effect of increasing levels of dietary potassium on rumen and fecal parameters

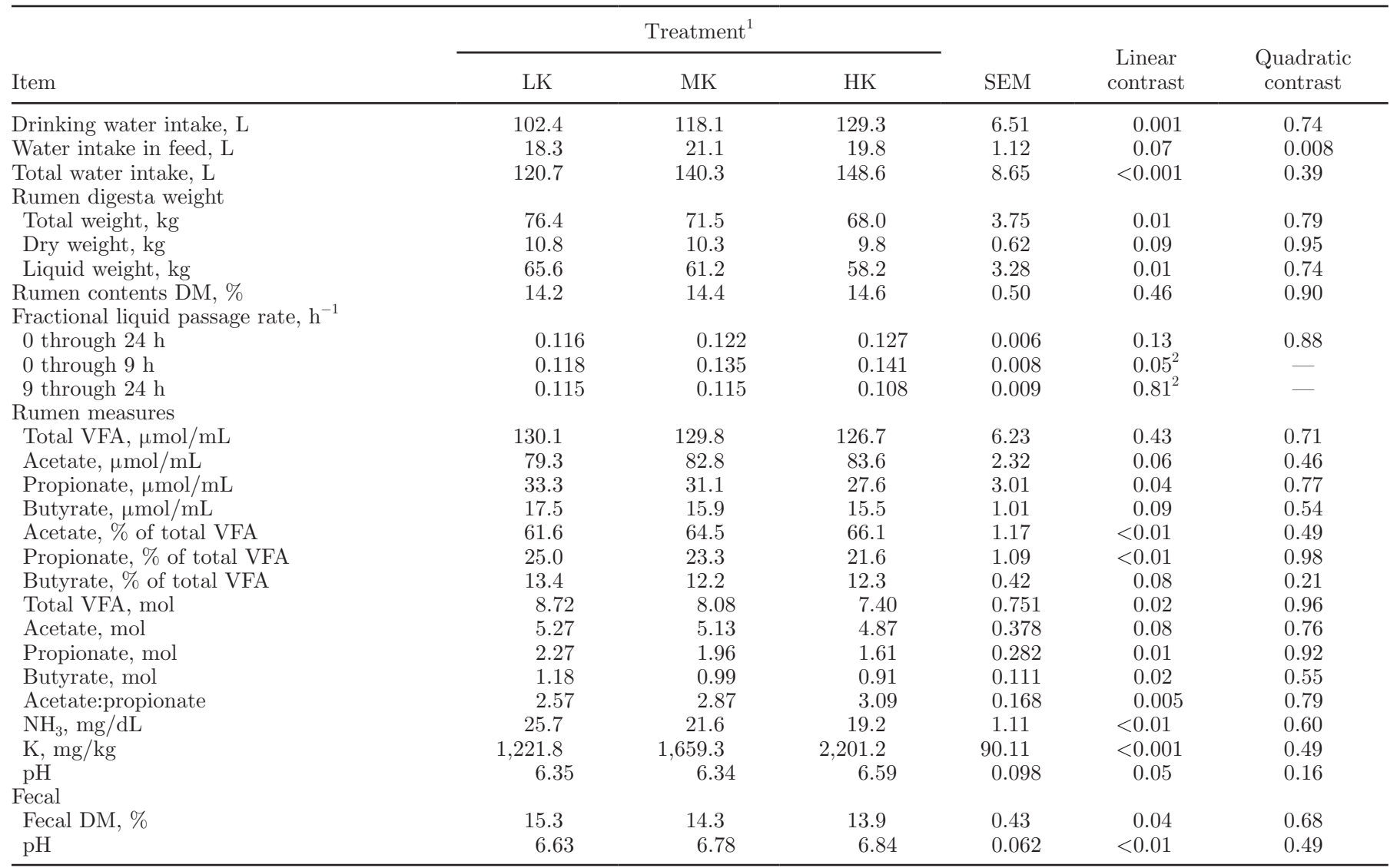

${ }^{1} \mathrm{LK}=$ baseline diet with $1.67 \%$ dietary $\mathrm{K} ; \mathrm{MK}=$ baseline diet with added $0.75 \%$ dietary $\mathrm{K}$; HK = baseline diet with added $1.5 \%$ dietary $\mathrm{K}$.

${ }^{2}$ Treatment-added K levels analyzed as a continuous variable.

potentially very different and incorrect interpretations as to the effect of $\mathrm{K}$ supplementation and other dietary changes.
When evaluating acetate, propionate, and butyrate as molar percentages of total VFA, differences were found among treatments. As dietary $\mathrm{K}$ increased in the

Table 6. Pearson correlation coefficients ( $P$-values in parentheses) of variables used in regressions to describe free water intake and fractional rumen liquid passage rate $(\mathrm{kp})$

\begin{tabular}{|c|c|c|c|c|c|c|c|c|}
\hline Item & $\begin{array}{l}\text { Free water } \\
\text { intake, L }\end{array}$ & $\begin{array}{c}\text { BW, } \\
\text { kg }\end{array}$ & $\begin{array}{l}\text { DMI, } \\
\text { kg }\end{array}$ & $\begin{array}{l}\text { Milk, } \\
\text { kg }\end{array}$ & $\begin{array}{c}\text { Feed K } \\
\text { intake, } \\
\mathrm{kg}\end{array}$ & $\begin{array}{c}\text { VFA, } \\
\text { mol }\end{array}$ & $\begin{array}{l}\text { Rumen } \\
\text { liquid, } \\
\text { kg }\end{array}$ & $\begin{array}{c}\text { Rumen } \\
\mathrm{DM}, \\
\mathrm{kg}\end{array}$ \\
\hline 0-to-9-h liquid $\mathrm{kp}, \mathrm{h}^{-1}$ & $\begin{array}{r}0.590 \\
(<0.01)\end{array}$ & $\begin{array}{c}0.295 \\
(0.14)\end{array}$ & $\begin{array}{c}0.225 \\
(0.27)\end{array}$ & $\begin{array}{c}0.073 \\
(0.72)\end{array}$ & $\begin{array}{c}0.447 \\
(0.02)\end{array}$ & $\begin{array}{c}-0.440 \\
(0.02)\end{array}$ & $\begin{array}{c}-0.281 \\
(0.16)\end{array}$ & $\begin{array}{c}-0.398 \\
(0.04)\end{array}$ \\
\hline Free water intake, $\mathrm{L}$ & & $\begin{array}{r}0.497 \\
(<0.01)\end{array}$ & $\begin{array}{r}0.433 \\
(0.02)\end{array}$ & $\begin{array}{c}0.334 \\
(0.09)\end{array}$ & $\begin{array}{r}0.618 \\
(<0.01)\end{array}$ & $\begin{array}{r}-0.189 \\
(0.35)\end{array}$ & $\begin{array}{r}-0.163 \\
(0.42)\end{array}$ & $\begin{array}{r}-0.054 \\
(0.79)\end{array}$ \\
\hline $\mathrm{BW}, \mathrm{kg}$ & & & $\begin{array}{r}0.501 \\
(<0.01)\end{array}$ & $\begin{array}{c}0.262 \\
(0.19)\end{array}$ & $\begin{array}{c}0.261 \\
(0.19)\end{array}$ & $\begin{array}{c}0.126 \\
(0.53)\end{array}$ & $\begin{array}{c}0.292 \\
(0.14)\end{array}$ & $\begin{array}{c}0.290 \\
(0.14)\end{array}$ \\
\hline Milk, $\mathrm{kg}$ & & & & & $\begin{array}{c}0.099 \\
(0.62)\end{array}$ & $\begin{array}{c}0.046 \\
(0.82)\end{array}$ & $\begin{array}{c}0.084 \\
(0.68)\end{array}$ & $\begin{array}{c}0.303 \\
(0.12)\end{array}$ \\
\hline Feed $\mathrm{K}$ intake, $\mathrm{kg}$ & & & & & & $\begin{array}{c}-0.299 \\
(0.13)\end{array}$ & $\begin{array}{c}-0.230 \\
(0.25)\end{array}$ & $\begin{array}{c}-0.284 \\
(0.15)\end{array}$ \\
\hline VFA, mol & & & & & & & $\begin{array}{r}0.872 \\
(<0.01)\end{array}$ & $\begin{array}{r}0.792 \\
(<0.01)\end{array}$ \\
\hline
\end{tabular}


diet, the molar percentage of acetate increased linearly while that of propionate decreased linearly $(P<0.01$ and $P<0.01$, respectively); butyrate tended to decrease as well $(P=0.08)$. Previous studies by Rogers et al. $(1979,1982)$ concluded that when rumen liquid dilution rates increased, acetate molar percentages increased but those of propionate decreased. A characteristic of buffers is an increase in rumen acetate and a decrease in rumen propionate, which is similar to what occurred in the present study (West et al., 1987). These same studies observed that total VFA concentrations decreased (Rogers et al., 1979, 1982); however, only numeric decreases were observed in the present study. West et al. (1987) concluded that a decrease in propionate production was likely due to removal of soluble substrates before they could be completely fermented. The decreases in rumen digesta DM mass and ruminal moles of VFA noted in the present study could be explained by increased passage of substrate from the rumen as dietary $\mathrm{K}$ increased.

Rumen $\mathrm{NH}_{3}$ differed among treatments, showing a linear decrease in $\mathrm{NH}_{3}$ concentrations as dietary $\mathrm{K}$ increased, even though CP intake had a quadratic effect $(P=0.05)$, with the cows receiving the MK diet consuming the most $\mathrm{N}$. The linear decrease in MUN concentrations in combination with declining ruminal $\mathrm{NH}_{3}$ concentrations suggest an overall decline in generation of $\mathrm{NH}_{3}$, ruminally or from other sources. The increased lkp and indication of increased ruminal turnover as K supplementation increased suggest that washout of undigested feed protein from the rumen may have played a role in the decline in rumen $\mathrm{NH}_{3}$, as compared with changes among treatments in absorption of $\mathrm{NH}_{3}$ across the rumen wall. Rumen $\mathrm{pH}$ linearly increased $(P<0.05)$ as $\mathrm{K}$ increased in the diets. The increase in $\mathrm{pH}$ appeared to be a direct result of buffering from the increasing addition of bicarbonate with $\mathrm{K}_{2} \mathrm{CO}_{3}$ (Kohn and Dunlap, 1998) or from the ruminal increase in soluble $\mathrm{K}$ (though not verified as ionized $\mathrm{K}$; Stewart, 1983) as ruminal VFA concentrations did not detectably differ among treatments (Table 5). A study by West et al. (1987) reported increases in rumen $\mathrm{pH}$ when cows were fed a diet that contained a buffer $(1.5 \%$ $\mathrm{NaHCO}_{3}, 1.25 \% \mathrm{~K}_{2} \mathrm{CO}_{3}$, or $1.85 \% \mathrm{~K}_{2} \mathrm{CO}_{3}$ ) as compared with those fed no buffer.

Fecal results are shown in Table 5 . Fecal pH linearly increased $(P<0.01)$ as the concentration of $\mathrm{K}(\mathrm{DM}$ basis) increased in the diet. Unlike the DM concentration of rumen contents, DM concentration of fecal matter decreased as dietary $\mathrm{K}$ increased, which is similar to what was found in previous research (Omer and Roberts, 1967). Omer and Roberts (1967) concluded that as K was increased in the diet, water intake was increased as well. Subsequently, there was an associated increase in fecal water along with an overall decrease in fecal DM percentage. In the present study, changes in fecal $\mathrm{pH}$ and $\mathrm{DM}$, as well as the increased water intake, decreased total and liquid rumen digesta amounts, and greater lkp noted from 0 to $9 \mathrm{~h}$ after Co-EDTA dosing associated with increased intake of $\mathrm{K}$, all give further indication that turnover rate in the rumen increased with increasing dietary K.

\section{CONCLUSIONS}

Total water intake increased linearly with increasing $\mathrm{K}_{2} \mathrm{CO}_{3}$ supplementation, with cows offered the HK diet consuming $28 \mathrm{~L} / \mathrm{d}$ more than the LK cows. Increased water intake could result in greater total water usage on farms and would potentially be a concern in areas where water availability is an issue. The early linear increases in fractional passage rate of liquid from the rumen that accompanied increased water intake could be the basis for increased washout of solids and liquid from the rumen, and provide explanation for the decrease in total and liquid ruminal digesta as $\mathrm{K}$ in the diets was increased. Molar proportions of VFA were also affected by dietary $\mathrm{K}$ levels. As $\mathrm{K}$ increased in the diet, acetate, as a percentage of total VFA, increased but propionate decreased. Water intake not only affects total milk production, but may also affect rumen parameters such as VFA proportions, rumen DM percentage, rumen turnover, and rumen $\mathrm{pH}$.

\section{ACKNOWLEDGMENTS}

The authors thank Mike Grott and the staff at the Purdue University Dairy Research and Education Center, West Lafayette, for daily cow care throughout the duration of the study.

\section{REFERENCES}

AOAC International. 2000. Official Methods of Analysis. 17th ed. AOAC Int., Gaithersburg, MD.

AOAC International. 2006. Official Methods of Analysis. 18th ed. AOAC Int., Gaithersburg, MD.

Appuhamy, J. A. D. R. N., C. Wagner-Riddle, D. P. Casper, J. France and E. Kebreab. 2014. Quantifying body water kinetics and fecal and urinary water output from lactating Holstein dairy cows. J. Dairy Sci. 97:6177-6195.

Bannink, A., H. Valk, and A. M. Van Vuuren. 1999. Intake and excretion of sodium, potassium, and nitrogen and the effects on urine production by lactating dairy cows. J. Dairy Sci. 82:1008-1018.

Beede, D. K. 2005. The most essential essential nutrient: Water. Proc. West. Dairy Manag. Conf. Reno, NV.

Delaquis, A. M., and E. Block. 1995. Dietary cation-anion difference, acid-base status, mineral metabolism, renal function, and milk production of lactating cows. J. Dairy Sci. 78:2259-2284.

Fearon, W. R. 1939. The carbamido diacetyl reaction: A test for citrulline. Biochem. J. 33:902-907.

Gasa, J., K. Holtenius, J. D. Sutton, M. S. Dhanoa, and D. J. Napper. 1991. Rumen fill and digesta kinetics in lactating Friesian cows 
given two levels of concentrates with two types of grass silage ad lib. Br. J. Nutr. 66:381-398.

Gressley, T. F., and L. E. Armentano. 2005. Effect of abomasal pectin infusion on digestion and nitrogen balance in lactating dairy cows. J. Dairy Sci. 88:4028-4044.

Hall, M. B., T. D. Nennich, and P. H. Doane. 2014. Total volatile fatty acid concentrations are unreliable estimates of treatment effects on in vivo ruminal fermentation. J. Dairy Sci. 97(E-Suppl. 1):302. (Abstr.)

Harrison, J. H., R. White, R. Kincaid, T. Jenkins, and E. Block. 2011. Potassium in the early lactation dairy cow and its impact on milk and milk fat production. WCDS Adv. Dairy Tech. 23:313-319.

Harrison, J., R. White, E. Kincaid, T. Block, Jenkins, and N. StPierre. 2012. Effectiveness of potassium carbonate sesquihydrate to increase dietary cation-anion difference in early lactation cows. J. Dairy Sci. 95:3919-3925.

Hu, W., and M. R. Murphy. 2004. Dietary cation-anion difference effects on performance and acid-base status of lactating dairy cows: A meta-analysis. J. Dairy Sci. 87:2222-2229.

Kohn, R. A., and T. F. Dunlap. 1998. Calculation of the buffering capacity of bicarbonate in the rumen and in vitro. J. Anim. Sci. 76:1702-1709

Murphy, M. R. 1992. Symposium: Nutritional factors affecting animal water and waste quality. Water metabolism of dairy cattle. J. Dairy Sci. 75:326-333.

Nennich, T. D., J. H. Harrison, L. M. VanWieringen, N. R. St-Pierre, R. L. Kincaid, M. A. Wattiaux, D. L. Davidson, and E. Block. 2006. Prediction and evaluation of urine and urinary nitrogen and mineral excretion from dairy cattle. J. Dairy Sci. 89:353-364.

NRC. 2001. Nutrient Requirements of Dairy Cattle. 7th rev. ed. Natl. Acad. Press, Washington, DC.

Omer, V. V. E. St., and W. K. Roberts. 1967. Some effects of dietary potassium upon digestibility, serum electrolytes and utilization of potassium, sodium, nitrogen, and water in heifers. Can. J. Anim. Sci. $47: 39-46$.

Roche, J. R., D. Dalley, P. Moate, C. Grainger, M. Rath, and F. O'Mara. 2003. Dietary cation-anion difference and the health and production of pasture-fed dairy cows. 1. Dairy cows in early lactation. J. Dairy Sci. 86:970-978.

Rogers, J. A., C. L. Davis, and J. H. Clark. 1982. Alteration of rumen fermentation, milk fat synthesis, and nutrient utilization with mineral salts in dairy cows. J. Dairy Sci. 65:577-586.

Rogers, J. A., G. C. Marks, C. L. Davis, and J. H. Clark. 1979. Alteration of rumen fermentation in steers by increasing rumen fluid dilution rate with mineral salts. J. Dairy Sci. 62:1599-1605.
Sanchez, W. K., D. K. Beede, and J. A. Cornell. 1994. Interactions of sodium, potassium, and chloride on lactation, acid-base status and mineral concentrations. J. Dairy Sci. 77:1661-1675.

Schneider, P. L., D. K. Beede, C. J. Wilcox, and R. J. Collier. 1984 Influence of dietary sodium and potassium bicarbonate and total potassium on heat-stressed lactating dairy cows. J. Dairy Sci $67: 2546-2553$

Squires, V. R. 1988. Water and Its Functions, Regulation and Comparative Use by Ruminant Livestock. Pages 217-226 in The Ruminant Animal Digestive Physiology and Nutrition. D. C. Church, ed. Prentice-Hall Inc., Englewood Cliffs, NJ.

Stewart, P. A. 1983. Modern quantitative acid-base chemistry. Can. J. Physiol. Pharmacol. 61:1444-1461.

Tucker, W. B., J. F. Hogue, D. F. Waterman, T. S. Swenson, Z. Xin, R. W. Hemken, J. A. Jackson, G. D. Adams, and L. J. Spicer. 1991 Rose of sulfur and chloride in the dietary cation-anion balance equation for lactating dairy cattle. J. Anim. Sci. 69:1205-1213.

Udén, P., P. E. Colucci, and P. J. Van Soest. 1980. Investigation of chromium, cerium and cobalt as markers in digesta. Rate of passage studies. J. Sci. Food Agric. 31:625-632.

Van Soest, P. J., J. B. Robertson, and B. A. Lewis. 1991. Methods for dietary fiber, neutral detergent fiber and non-starch polysaccharides in relation to animal nutrition. J. Dairy Sci. 74:3583-3597.

Voelker Linton, J. A., and M. S. Allen. 2008. Nutrient demand interacts with forage family to affect intake and digestion responses in dairy cows. J. Dairy Sci. 91:2694-2701.

West, J. W., C. E. Coppock, K. Z. Milam, D. H. Nave, and J. M. Labore. 1987. Potassium carbonate as a potassium source and dietary buffer for lactating Holstein cows during hot weather. J. Dairy Sci. 70:309-320.

West, J. W., C. E. Coppock, D. H. Nave, and G. T. Schelling. 1986 Effects of potassium buffers on feed intake in lactating dairy cows and on rumen fermentation in vivo and in vitro. J. Dairy Sci 69:124-134.

West, J. W., B. G. Mullinix, and T. G. Sandifer. 1991. Changing dietary electrolyte balance for dairy cows in cool and hot environments. J. Dairy Sci. 74:1662-1674.

Wybenga, D. R., J. Di Giorgio, and V. J. Pileggi. 1971. Manual and automated methods for urea nitrogen measurement in whole serum. Clin. Chem. 17:891-895. 